1994

\title{
Logic and Experience: The Origin of Modern American Legal Education
}

William P. LaPiana

New York Law School, william.lapiana@nyls.edu

Follow this and additional works at: https://digitalcommons.nyls.edu/fac_books

\section{Recommended Citation}

LaPiana, William P., "Logic and Experience: The Origin of Modern American Legal Education" (1994). Books. 99.

https://digitalcommons.nyls.edu/fac_books/99

This Article is brought to you for free and open access by the Faculty Scholarship at DigitalCommons@NYLS. It has been accepted for inclusion in Books by an authorized administrator of DigitalCommons@NYLS. 


\section{LOGIC AND EXPERIENCE}

\section{The Origin of Modern American Legal Education}

\section{William P. LaPiana}

New York Oxford OXFORD UNIVERSITY PRESS

1994 


\author{
Oxford University Press \\ Oxford New York Toronto \\ Dehli Bombay Calcutta Madras Karachi \\ Kuala Lumpur Singapore Hong Kong Tokyo \\ Nairobi Dar es Salaam Cape Town \\ Melbourne Auckland Madrid \\ and associated companies in \\ Berlin Ibadan
}

Copyright (C) 1994 by Oxford University Press, Inc.

Published by Oxford University Press, Inc.

200 Madison Avenue, New York, New York 10016

Oxford is a registered trademark of Oxford University Press

All rights reserved. No part of this publication may be reproduced, stored in a retrieval system, or transmitted, in any form or by any means, electronic, mechanical, photocopying, recording, or otherwise, without the prior permission of Oxford University Press.

Library of Congress Cataloging-in-Publication Data LaPiana, William P.

Logic and experience : the origin of modern American legal education / William P. LaPiana.

p. $\mathrm{cm}$.

ISBN 0-19-507935-3

1. Law-Study and teaching-United States-History. 2. Case method-History. I. Title.

KF272.L27 1994

349.73-dc20 [347.3] 93-21928

246897531

Printed in the United States of America on acid-free paper 


\section{Contents}

1. Introduction, 3

2. Harvard's Transformation, 7

Appointing a Dean, 7

Developing a Law School, 14

Birth of the Case Method, 22

3. Antebellum Legal Education, 29

A Science of Principles, 29

A Practical Science of Procedure, 38

Education in Legal Science, 44

4. Case Method and Legal Science, 55

A Science of Narrow Rules, 55

A Technical Science of Contracts and Equity, 58

Changes in Procedure and Legal Thought, 70

5. Harvard and the Legal World, 79

The Struggle for Standards in New York, 79

Case Method Comes to Columbia, 92

Case Method and Practice, 99

6. A New Legal Science, 110

Fact-Based Legal Science, 110

Harvard Teachers and Positive Law, 122

7. Opposition, 132

The Case Lawyer, 132

The Evils of Positivism, 138

8. Reconciliation, 148

The Spread of the Case Method, 148 
The Failure of Sociological Jurisprudence, 152 The American Law Institute, 158

The Coming of Realism, 164

Epilogue, 168

Notes, 171

Bibliography, 221

Index, 243 


\section{Introduction}

The appointment of Christopher Columbus Langdell as Dane Professor at Harvard Law School on January 6,1870 , is widely acknowledged to mark the beginning of the modern American law school. ${ }^{1}$ Langdell's discovery of a new world of legal education was only a start. His disciples, especially James Barr Ames and William A. Keener, developed what we recognize today as the case method of legal education. ${ }^{2}$ What generally has been overlooked, however, is Alfred Z. Reed's observation "that literally all good things are not first thought of in Cambridge" and "except on the score of practicality, there was nothing startlingly original in [Langdell's] idea." ${ }^{3}$ Reed was clearly on the right track. Aspects of Langdell's method of teaching, his beliefs about the scientific nature of law, and the rhetoric with which he justified them resembled those of the past. Yet the first dean of Harvard Law School has acquired the reputation of an innovator of the first order, and a perverse innovator at that. His thought-and by extension the form of legal education he helped create-has been identified as one of the principal sources of the sterile formalism that supposedly marked late nineteenth-century American legal thought. ${ }^{4}$

It is clear that Langdell's view of law emphasized the logical coherence of legal rules. In Langdell's formulation, legal education is the study of a few fundamental principles that are found in the original sources-casesand, by implication, are derived from those cases by the process of induction. Thus the student thinks for himself rather than merely accepts the secondhand formulation of some treatise writer. This construct justified the study of law as a science.

When it comes to deciding what was new in Langdell's thought, Reed had it partly right. Langdell's ideas do share certain qualities with those of the preceding generation of American legal thinkers. Teasing out the innovative from the continuing opens a new prospect on late nineteenthcentury American legal thought; it also sheds new light on the significance of the changes in legal education associated with Langdell's tenure at Harvard. Any such effort must be grounded in an attempt to understand the intellectual world in which Langdell lived his life in the law. For purposes of analysis, that world can be divided into two parts: the realm of law as ideas-as a system of principles that must be rightly understood if society 
is to be correctly governed; and the realm of law as procedure-as a system of rules for resolving disputes in the courts, knowledge of which gives lawyers an opportunity to make a living.

Langdell's professional world underwent significant change in both aspects during his lifetime. After the Civil War more than one thoughtful American lawyer turned their minds to the idea of law as science and subsequently encountered the writings of John Austin. Some recoiled in horror; some, often those most involved with transforming legal education, found something that struck a chord, that resonated truly. The spread of the new structure of pleading (which was embodied in the code of procedure-the Field Code-written primarily by David Dudley Field and first enacted in New York in 1848) helped change the way lawyers put the law into action, a change Langdell lived as a practitioner in New York. ${ }^{5}$ Both developments helped shape Langdell's legal science.

The legal profession does not exist in a vacuum, of course, and the changes that occurred at Harvard during Langdell's deanship parallel changes in society as a whole: changes in ideas of pedagogy; changes in ideas about the sort of training that would equip young men for life in the world; changes in the nature of professionalism and in the structure of the legal profession. Modernization is a term used so often in historical explanation that it sometimes seems to be bereft of meaning. If the modern is equated with ideas and social structures we recognize as more like those of the present day than not, however, it can be said that Langdell and his colleagues lived during, gave impetus to, and even helped shape the modernization of American legal education and legal thought.

The chapters that follow sketch the intellectual and institutional history of these changes. In chapter 2 , the often told story of the changes the new dean brought to the law school in Dane Hall is placed in the context of larger changes in both the university and society. To a great degree the narrative becomes the story not of Langdell, but of Charles William Eliot, whose vision informed not only the institutional nature of the law school, but even to some degree its most distinctive educational attribute-the case method. The case method, viewed as a method of instruction, is put into the context of changing ideas of pedagogy in higher education and changing social visions of the way young men are to make their way in the world. In order to emphasize further the degree of change that overtook American legal education and legal thought after the Civil War, chapter 3 describes the alien world of antebellum legal thought and education. Antebellum legal science had two aspects: one shared the general American view of science as the process of inducing from facts general principles which in the end are reflections of the mind of the Creator; the other was based on the supremely useful technical science of common law pleading. Antebellum legal education drew on both sorts of legal science, although antebellum law schools were devoted primarily to inculcating the science of principles, a process that was not particularly rigorous or demanding.

Chapter 4 investigates in detail Langdell's writings on contracts and 
equity procedure to investigate the case method as an approach to understanding the law rather than as a pedagogical tool. Langdell's legal science is described as a modification of the antebellum science of broad principles in the direction of narrow, technical expertise. This change in focus is traced to the influence of broad social and intellectual change, especially the growth of the positivistic view of law as the command of a sovereign rather than as the reflection of eternal right, and to the highly technical changes in practice and procedure brought about by the adoption of the Field Code in New York, where Langdell practiced for more than a decade before returning to Harvard as dean. The new legal science, then, was the product of changes in both broad and technical aspects of the antebellum legal world.

The relationship between the changing law school and the legal profession is the subject of chapter 5, which necessarily focuses on broader themes of social change. Whatever the novelty or wisdom of Langdell's approach to legal education, the success of the reforms at Harvard seems to require more explanation than the talents or luck of its dean. Just as Langdell's views mixed elements of high abstraction and the influence of the techniques of practice, the success of his school rested on the service it performed, both in meeting the needs of the bar for social position and prestige and in training young men for the realities of practice in a legal world transformed by an early version of the information explosion. The relationship between case method legal education and social standing is illustrated by a discussion of the revolution that swept Columbia's law school when the Langdell method supplanted traditional teaching. The importance of practical training is shown by tracing the growth of law reporting and the concomitant growing importance of research in the decided cases as the principal technique of legal practice.

Langdell's colleagues in the first generation of modern law teachers appear in chapter 6 , where their thoughts, as well as those of Nicholas St. John Green and Oliver Wendell Holmes, Jr., are analyzed in terms of positivism, the heart of the new legal science.

While much of modern American legal education and legal thought seems to have appealed to at least the most articulate members of the profession, the new method held its terrors, which chapter 7 describes. The rise of law schools as the setting for legal education, supplanting law offices, led some practitioners to emphasize the need to educate prospective lawyers in the skills of practice. The resulting attack on the diploma privilege actually received the support of Langdell and Eliot, support that emphasizes the degree to which new ideas of legal education differed from the old. Some of the fears and doubts, however, were directly related to the idea of law promoted by teachers working at the reformed Harvard Law School and were not so easily allayed. The case method, in fact, became a prime focus of discontent. For some critics of the new law school, the case method threatened their own cherished view of the nature of law. Their vision lived for a time at Yale Law School, only to be sup- 
planted in the early twentieth century by the Harvard model. Just as the revolution at Columbia illustrated the social power of the case method law school, the evolution at Yale illustrates the changing intellectual underpinnings of legal education.

Opposition finally began to disappear, however, with the new century. Chapter 8 examines some of the factors leading to détente, and places special emphasis on the American Law Institute as the means of reconciliation between school and profession.

What follows, then, is an attempt to place the history of the formative years of modern American legal education in as complete a context as possible. It is an attempt to write a cultural history, a story of both intellectual and social change in one area of American life. The area is a limited one, at least when the number of people directly involved is taken into account. A handful of professors, a small number of articulate practitioners who may have taught a bit, a university administrator here and there, and perhaps a few thousand students, all male, are the actors and the audience. What they set in motion, however, has had broad repercussions. Their creation triumphed as the model for legal education. As the American legal profession grew in numbers and influence, the importance of understanding the roots of modern legal education has also increased-or at least become more interesting. American legal education in the late twentieth century is in the midst of a period of intense introspection and selfcriticism. Much of this self-analysis has focused on the history of the enterprise. Most earlier historians have been concerned primarily with the unique contribution of that first generation of teachers, especially Langdell: the case method and the idea of law which was assumed to underlay it. The final conclusion of this work, however, is that the story is more complex, and the forces involved in the creation of the modern law school are more varied than has been realized. 